\title{
Gonadotropin-releasing hormone agonists suppress melanoma cell motility and invasiveness through the inhibition of $\alpha 3$ integrin and MMP-2 expression and activity
}

\author{
ROBERTA M. MORETTI, MARINA MONTAGNANI MARELLI, STEFANIA MAI and PATRIZIA LIMONTA \\ Center of Endocrinological Oncology, Institute of Endocrinology, University of Milan, Milan, Italy
}

Received February 26, 2008; Accepted April 17, 2008

DOI: 10.3892/ijo_00000022

\begin{abstract}
Cutaneous melanoma represents the leading cause of skin cancer deaths. The prognosis of highly aggressive, metastatic melanoma is still very poor, due to the resistance of the disseminated tumor to existing therapies. The clarification of the molecular mechanisms regulating melanoma growth and progression might help identify novel molecular targets for the development of new therapeutic interventions. We previously showed that gonadotropin-releasing hormone $(\mathrm{GnRH})$ receptors are expressed in melanoma cells; activation of these receptors by means of GnRH agonists significantly reduces cell proliferation. In the current study, we first showed that GnRH agonists significantly reduced the metastatic behavior of melanoma cells in terms of both cell motility (haptotactic assay using laminin as the chemoattractant) and invasiveness (cell invasion assay evaluating the capacity of the cells to invade a reconstituted extracellular matrix barrier). On the basis of this observation, we then investigated the molecular mechanisms underlying the antimetastatic activity of GnRH agonists. We found that, in melanoma cells, a) the activity of the $\alpha 3$ integrin subunit is crucial for the migratory behavior of the cells; b) GnRH agonists significantly reduced $\alpha 3$ integrin expression (Western blotting and immunofluorescence studies); c) GnRH agonists significantly reduced MMP-2 expression (comparative RT-PCR) and activity (zymographic analysis performed on cell culture media). These data indicate that $\mathrm{GnRH}$ agonists, in addition to the previously reported antiproliferative effect, elicit a strong inhibitory activity on the migratory/invasive behavior of melanoma cells expressing GnRH receptors. These compounds reduce the metastatic potential of melanoma cells by interfering with the expression/activity of cell adhesion molecules ( $\alpha 3$ integrin) and matrix metalloproteinase (MMP-2).
\end{abstract}

Correspondence to: Dr Patrizia Limonta, Center of Endocrinological Oncology, Institute of Endocrinology, University of Milan, via Balzaretti 9, I-20133 Milan, Italy

E-mail: patrizia.limonta@unimi.it

Key words: melanoma, migration, invasion, gonadotropin-releasing hormone, integrins, matrix metalloproteinase-2

\section{Introduction}

Cutaneous melanoma, the most malignant tumor of the skin, still represents the leading cause of skin cancer deaths $(1,2)$. The tumor initially starts with a radial-growth phase (RGP) which can rapidly progress to a vertical-growth phase (VGP). In this last stage, melanoma cells are characterized by a high proliferation rate and by a strong ability to give rise to metastases $(3,4)$. Although early detection and improved surgical techniques have led to an absolute increase in patient survival, the prognosis of highly aggressive, metastatic melanoma is still very poor, due to the resistance of the disseminated tumor to existing therapies (5-8). A better understanding of the molecular mechanisms underlying melanoma growth, invasiveness and metastatic dissemination might help identify novel molecular markers for the development of new targeted therapeutic interventions.

The progression of melanoma has been shown to be associated with changes in the expression and/or activity of cell adhesion molecules such as integrins and cadherins (9-12) as well as of enzymes involved in the remodeling of the extracellular matrix such as matrix metalloproteinases (MMPs) and urokinase-type plasminogen activator (uPA) $(13,14)$. Endogenous growth factors known to regulate tumor vascularization, such as VEGF, have also been shown to play a crucial role in the acquisition of proangiogenic and metastatic properties by melanoma cells $(11,15,16)$. However, the regulation of the synthesis and/or activity of these molecules is still unclear. Endogenous factors produced either by host cells or by tumor cells themselves have been proposed to be deeply involved in these processes (17).

Gonadotropin-releasing hormone $(\mathrm{GnRH})$ is the well known master regulator of reproductive functions. After being secreted by hypothalamic neurons into the pituitary portal vessels, GnRH binds to specific receptors on gonadotropes and stimulates gonadotropin synthesis and secretion, thus regulating gonadal functions (18). GnRH agonists, when administered continuously and at high doses, suppress gonadal steroid secretion through the desensitization of pituitary GnRH receptors. On the basis of this activity, GnRH agonists are successfully utilized for the treatment of hormone-dependent pathologies, such as steroid-dependent cancers (19-22). GnRH receptors have been also reported to be expressed in tumors of the reproductive tract (i.e., prostate, breast and endometrial cancer), and their activation has been shown to be coupled 
with a significant reduction in tumor cell proliferation and metastatic behavior (23-27). Thus, it is now believed that, when utilized for the treatment of hormone-related cancers, in addition to their suppressive action on the pituitarygonadal axis, GnRH agonists might also exert an additional, specifically targeted, antitumor activity.

In a previous study, we showed that receptors for $\mathrm{GnRH}$ are expressed in human melanoma cells (a tumor classically unrelated to the endocrine system), and activation of these receptors by means of GnRH agonists significantly decreased cell proliferation and motility behavior. These effects are specific, since they are completely abrogated by GnRH antagonists (28). On the basis of these observations, the present experiments were performed to clarify the molecular mechanisms underlying the antitumor activity of GnRH agonists on melanoma cells.

\section{Materials and methods}

Materials. The GnRH agonist Goserelin acetate (Zoladex, D$\left.\operatorname{Ser}(\mathrm{tBu})^{6} \mathrm{Aza}-\mathrm{Gly}{ }^{10}-\mathrm{GnRH} ; \mathrm{GnRH}-\mathrm{A}\right)$ and laminin were purchased from Sigma Chemical Co. (St. Louis, MO). Mouse function-blocking antibody against human $\alpha 3$ integrin (MAB 1952Z) and goat polyclonal primary antibody against human a3 integrin (sc-6592; for Western blotting and immunofluorescence analysis) were from Chemicon (Temecula, CA) and from Santa Cruz Biotechnology (Santa Cruz, CA), respectively.

Cell cultures. The human melanoma BLM cell line, possessing a high proliferative and metastatic potential (29), was kindly donated by Dr G.N.P. van Muijen (Department of Pathology, University Hospital Nijmegen, The Netherlands). BLM cells were cultured in DMEM medium (Seromed, Biochrom KG, Berlin, Germany), supplemented with $10 \%$ fetal bovine serum (FBS; Gibco, Paisley, Scotland), glutamine $(1 \mathrm{mM})$, antibiotics $(100 \mathrm{IU} / \mathrm{ml}$ penicillin $\mathrm{G}$ sodium, $100 \mu \mathrm{g} /$ $\mathrm{ml}$ streptomycin sulfate) and sodium pyruvate $(100 \mathrm{nM})$ in a humidified atmosphere of $5 \% \mathrm{CO}_{2} / 95 \%$ air.

Haptotactic assays. To evaluate the motility of BLM cells towards a chemoattractant, haptotactic assays were conducted using 48-well Boyden chambers (Neuroprobe, Cabin John, MD) in which each pair of wells were separated by polyvinylpyrrolidone-free polycarbonate porous membrane $(8 \mu \mathrm{m}$ pore size), as previously described (30). In preliminary experiments, we found that BLM cells actively migrated towards laminin $\left(1.5 \mu \mathrm{g} / \mathrm{cm}^{2}\right)$ (data not shown). This protein of the extracellular matrix was previously shown to specifically interact with $\alpha 3$ integrin in melanoma cells (9). Thus, laminin was utilized in the subsequent experiments. The dose of GnRH-A utilized throughout all the experiments $\left(10^{-6} \mathrm{M}\right)$ was selected on the basis of previously published observations $(28,30)$.

Experiment 1. BLM cells were grown for 5 days in complete medium, either in the absence (controls) or in the presence of GnRH-A ( $\left.10^{-6} \mathrm{M}\right)(28)$. Cells were then placed in the open-bottom wells of the upper compartment of a Boyden chamber $\left(2 \times 10^{5}\right.$ cells/well $)$ in which the lower surface had been precoated with laminin $\left(1.5 \mu \mathrm{g} / \mathrm{cm}^{2}\right.$ membrane $)$. The lower compartments of the chambers were filled with serumfree medium. The chambers were kept in the cell culture incubator for $4 \mathrm{~h}$. Cells that had migrated through the pores and found adherent to the underside of the membrane were fixed, stained (DiffQuick kit; Dade, Dudingen, $\mathrm{CH}$ ) and mounted onto glass slides. Six random objective fields of stained cells were counted for each well (eight wells per experimental group), and the mean cell number of migrating cells $/ \mathrm{mm}^{2}$ was calculated. The effects of GnRH-A on cell migration cannot be explained by decreased cell proliferation since the haptotactic assay period is too short $(4 \mathrm{~h})$ for detecting a possible antiproliferative effect (28).

Experiment 2. To clarify the role of $\alpha 3$ integrin in BLM cell migration, cells were cultured for $1 \mathrm{~h}$ in complete medium, either in the absence (controls) or in the presence of a functionblocking antibody against $\alpha 3(10 \mu \mathrm{g} / \mathrm{ml})$. Cells were then harvested and seeded in the open-bottom wells of the upper compartment of a Boyden chamber $\left(2 \times 10^{5}\right.$ cells/well $)$ in which the lower surface had been precoated with laminin $\left(1.5 \mu \mathrm{g} / \mathrm{cm}^{2}\right.$ membrane). The experiment was then performed as described above.

Each experiment was repeated three times. Data were analyzed by one-way ANOVA followed by Bonferroni's test.

Invasion assay. Cell invasion experiments were conducted using the QCP ${ }^{\text {тм }}$ 24-well Cell Invasion Fluorimetric Assay (Chemicon) with ECMatrix ${ }^{\mathrm{TM}}$-coated inserts, according to the manufacturer's instructions. This assay provides an efficient system for a quantitative evaluation of the invasion of tumor cells through a basement membrane model. BLM cells were grown, for 5 days, in complete medium, either in the absence (controls) or in the presence of GnRH-A $\left(10^{-6} \mathrm{M}\right)$. At the end of the treatment, cells were suspended in serum-free medium and seeded $\left(2.5 \times 10^{5}\right.$ cells $\left./ 250 \mu \mathrm{l}\right)$ in each insert of a multiwell plate chamber. In the lower chamber, culture medium supplemented with $10 \%$ FBS was added as the chemoattractant. After a 48 -h incubation period at $37^{\circ} \mathrm{C}$, the noninvading cells were removed from the top of the inserts. Next, the inserts were placed into a well containing a prewarmed cell detachment solution $(225 \mu \mathrm{l})$ and incubated at $37^{\circ} \mathrm{C}$ for $30 \mathrm{~min}$. The inserts were removed from the wells, and a lysis buffer/dye solution was added to the medium containing the detached cells for $15 \mathrm{~min}$ at room temperature. The mixtures were then read with a fluorescence plate reader using a 485/515 nm filter set. Fluorescence measurements were reported as RFU (relative fluorescence unit) values. As underlined for the haptotactic assay (Experiment 1), the effects of GnRH-A on cell invasiveness cannot be explained by decreased cell proliferation since the invasion assay period is too short $(48 \mathrm{~h})$ for detecting a possible antiproliferative effect (28).

Western blotting. To clarify whether GnRH agonists could affect the levels of $\alpha 3$ integrin protein, BLM cells were grown in complete medium for 5 days, either in the absence (controls) or in the presence of GnRH-A $\left(10^{-6} \mathrm{M}\right)$. Cells were then washed with PBS and lysed with RIPA buffer [50 mM Tris- $\mathrm{HCl}$ (pH 7.7), $150 \mathrm{mM} \mathrm{NaCl}, 0.8 \%$ Triton X-100, 0.8\% sodium deoxycholate, $0.08 \% \mathrm{SDS}, 10 \mathrm{mM}$ EDTA, $100 \mu \mathrm{M}$ $\mathrm{Na}_{3} \mathrm{VO}_{4}, 50 \mathrm{mM} \mathrm{NaF}, 0.3 \mathrm{mM}$ PMSF, $5 \mathrm{mM}$ iodoacetic acid] 
containing leupeptin and aprotinin $(1 \mu \mathrm{g} / \mathrm{ml})$. The extracts were centrifuged to remove insoluble materials. Protein contents were determined using the BCA method. Equal amounts of proteins $(60 \mu \mathrm{g})$ for each experimental sample were resuspended in sample buffer, separated by $7.5 \%$ SDSPAGE polyacrylamide gels, and transferred onto nitrocellulose membranes. Membranes were blocked in 5\% BSA before incubation at room temperature for $1 \mathrm{~h}$ with the primary anti$\alpha 3$ antibody (sc-6592; 1:1,000). Detection was carried out using a horseradish peroxidase-conjugated reagent (Supersignal Chemiluminescence Detection System, Pierce Biotechnology Inc., Rockford, IL). The experiment was repeated three times.

Immunofluorescence analysis. BLM cells were seeded $\left(15 \times 10^{3}\right.$ cells/coverslip) on $13-\mathrm{mm}$ glass coverslips coated with laminin $\left(1.5 \mu \mathrm{g} / \mathrm{cm}^{2}\right)$ and grown for 5 days in complete medium either in the absence (controls) or in the presence or GnRH-A $\left(10^{-6} \mathrm{M}\right)$. Cells were then fixed with $3 \%$ paraformaldehyde in $2 \%$ sucrose PBS for $10 \mathrm{~min}$ and incubated with the unlabeled anti- $\alpha 3$ primary antibody (sc-6592; 1:100), followed by TRITC-conjugated rabbit anti-goat secondary antibody (Alexa Fluor 488). Labeled cells were examined under a Zeiss Axiovert 200 microscope with a $63 \times 1.4$ objective lens. Images were captured using the Metavue program and analyzed using Adobe Photoshop 6.0. Each staining was repeated three times for three different preparations for each group.

RT-PCR analysis. BLM cells (2x105/well) were plated in 10well plastic dishes and after 2 days were grown, either in the absence (controls) or in the presence of GnRH-A $\left(10^{-6} \mathrm{M}\right)$ for different time intervals $(6,12,24,36,48$ and $72 \mathrm{~h})$. Total RNA from BLM cells was prepared with the use of the RNeasy mini kit (Qiagen, Chatsworth, CA), according to the manufacturer's instructions. Reverse transcription (RT) was performed on $2 \mu \mathrm{g}$ of total RNA, and cDNA synthesis was performed using the Gene AMPkit (Perkin Elmer Cetus, Norwalk, CT) with an oligo(dT) ${ }_{16}$ as a primer. For MMP-2 cDNA amplification, PCR was performed for 25 cycles $\left(94^{\circ} \mathrm{C}\right.$ for $45 \mathrm{sec}, 59^{\circ} \mathrm{C}$ for $1 \mathrm{~min}, 72^{\circ} \mathrm{C}$ for $\left.90 \mathrm{sec}\right)$ in the presence of the following primers: upstream primer $5^{\prime}-\mathrm{GTG}$ CTGAAGGACACACTAAAGAAGA-3' (2 pmol) and downstream primer 5'-TTGCCATCCTTCTCAAAGTTGT AGG-3' (2 pmol) (31). For TIMP-2 cDNA amplification, PCR was performed for 25 cycles $\left(94^{\circ} \mathrm{C}\right.$ for $45 \mathrm{sec}, 59^{\circ} \mathrm{C}$ for $1 \mathrm{~min}, 72^{\circ} \mathrm{C}$ for $90 \mathrm{sec}$ ) in the presence of the following primers: upstream primer 5'-AAACGACATTTATGGCAA CCCTATC-3' (2 pmol) and downstream primer 5'-ACAGG AGCCGTCACTTCTCTTGATG-3' (2 pmol) (31). B-actin was amplified using specific sets of primers. After PCR, the amplified cDNA products were separated on $1.5 \%$ agarose gels stained with ethidium bromide and visualized under ultraviolet light. The experiments were repeated three times.

Zymographic analysis. BLM cells were seeded in flasks at a density of $8.5 \times 10^{5}$ cells/flask. After 2 days, serum-free medium was added to the culture flasks, and cells were grown either in the absence (controls) or in the presence of GnRH-A $\left(10^{-6} \mathrm{M}\right)$ for different time intervals $(24-72 \mathrm{~h})$. The activity of
MMP-2 in the conditioned medium was assessed by zymography. The conditioned media, from control and treated cells, were collected, centrifuged at $8,000 \mathrm{rpm}$ for $10 \mathrm{~min}$ at $4^{\circ} \mathrm{C}$ and resuspended in non-reducing SDS-polyacrylamide gel electrophoresis sample buffer. Samples were separated on $7.5 \%$ polyacrylamide gels containing $1 \mathrm{mg} / \mathrm{ml}$ gelatin. After electrophoresis, gels were washed three times in $2.5 \%$ Triton $\mathrm{X}-100$ for $10 \mathrm{~min}$, two times in substrate buffer (1X) containing $50 \mathrm{mM}$ Tris- $\mathrm{HCl}$ (pH 7.5), $5 \mathrm{mM} \mathrm{CaCl}_{2}, 200 \mathrm{mM} \mathrm{NaCl}$, $0.02 \%$ Brij-35 (Bio Rad), and incubated in the same buffer at $37^{\circ} \mathrm{C}$ overnight. Gels were stained for $60 \mathrm{~min}$ in $40 \%$ methanol/ $10 \%$ glacial acetic acid containing $0.1 \%$ Coomassie Brilliant Blue R250 and destained in the same solution without Coomassie Brilliant Blue. MMP-2 activity was visualized in the gelatin-containing zymograms as clear bands against a blue background and quantified by densitometric analysis of zymographic bands. Zymography was performed three times for each sample.

\section{Results}

GnRH agonists reduce melanoma cell migratory and invasive behavior. In a previous study (28) we showed that $\mathrm{GnRH}$ agonists reduced the motility (chemotactic assay against an aspecific stimulus, FBS) and the invasive capacity of melanoma cells, when grown in a Matrigel preparation (Matrigel gel assay). Experiments were performed to confirm these observations, by means of different, and more accurate, experimental techniques. First, we utilized a haptotactic assay to study the effects of GnRH-A on the ability of BLM cells to migrate towards laminin. Laminin is a protein of the extracellular matrix, which has been shown to regulate melanoma cell motility, through its specific binding to the $\alpha 3$ integrin subunit (9). We observed that pretreatment of BLM cells (5 days) with GnRH-A significantly reduced their migratory behavior (Fig. 1A). The effects of GnRH agonists on the invasive capacity of melanoma cells were investigated by means of a fluorimetric cell invasion assay, which analyzes the ability of the cells to invade a reconstituted extracellular matrix barrier. This method allows a quantitative evaluation of the effect and, therefore, a statistical analysis of the results. We found that, when serum-free medium was placed in the lower compartment of the wells, the invasive properties of the cells were very low (data not shown). In the presence of $10 \%$ FBS-supplemented medium, the cells actively invaded the extracellular matrix preparation to migrate towards the chemoattractant; pretreatment of the cells with GnRH-A significantly reduced their invasive capacity (Fig. 1B).

GnRH agonists reduce a 3 integrin expression in melanoma cells. It was previously shown that different integrins, through their interaction with proteins of the extracellular matrix, are deeply involved in melanoma cell motility (9). We performed preliminary experiments to clarify the role of the $\alpha 3$ integrin subunit in the control of the migratory behavior of BLM cells, as previously described for other melanoma cell lines (9). By means of a haptotactic assay, using laminin as the chemoattractant, we demonstrated that, when BLM cells were grown in the presence of a function-blocking antibody against $\alpha 3$, the ability of these cells to migrate towards laminin was 
A)

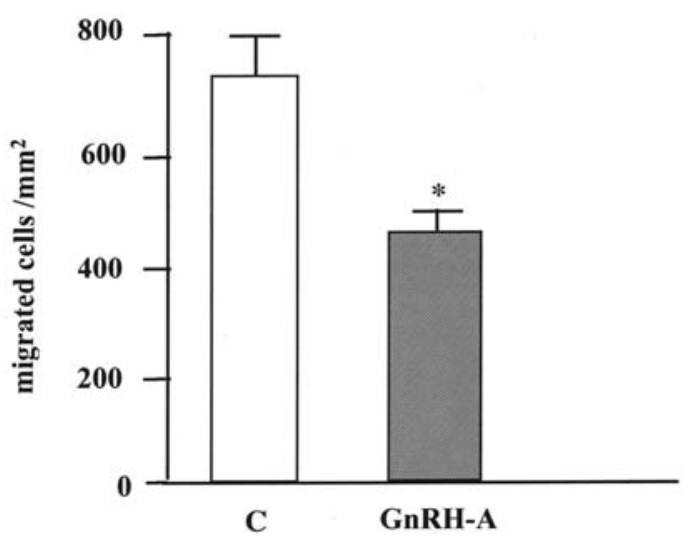

B)

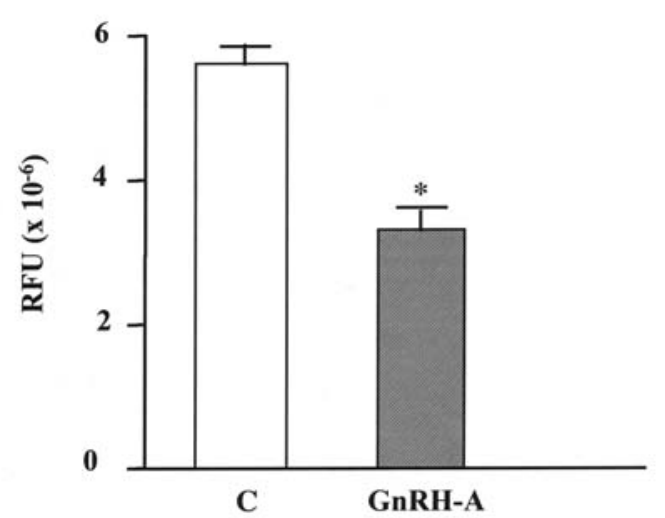

Figure 1. Effects of GnRH-A on melanoma cell migratory (A) and invasive behavior (B). (A) BLM cells were treated for 5 days with GnRH-A $\left(10^{-6} \mathrm{M}\right)$. Cells were then seeded in the open-bottom wells of the upper compartment of a Boyden chamber for which the lower surface had been precoated with laminin (chemoattractant) for the haptotactic assay. Data are expressed as the mean number of migrated cells $/ \mathrm{mm}^{2} \pm \mathrm{SE}$. (B) BLM cells were treated for 5 days with GnRH-A $\left(10^{-6} \mathrm{M}\right)$. The invasive ability of the cells was then evaluated using the QCP Cell Invasion Fluorimetric Assay with ECMatrixcoated inserts, according to the manufacturer's instructions. Fluorescence measurements, corresponding to the number of cells that invaded the Matrigel preparation, were reported as RFU (relative fluorescence unit) values $\pm \mathrm{SE} .{ }^{*} \mathrm{P}<0.05$ vs. $\mathrm{C}$, controls.

significantly reduced (Fig. 2A and B). Thus, this integrin subunit, through its binding to the extracellular matrix protein laminin, plays a crucial role in BLM cell motility. Based on this observation, we investigated whether GnRH agonists might exert their antimotility effect by modulating the expression of this integrin. First of all, immunofluorescence staining for $\alpha 3$ integrin was performed in BLM cells pretreated (5 days) with GnRH-A. Fig. 3A shows that, in untreated control cells, $\alpha 3$ integrin was highly expressed, mainly localizing at the level of the cell surface; treatment of the cells with GnRH-A substantially reduced $\alpha 3$ immunofluorescence staining. In agreement with this observation, we further demonstrated that GnRH-A, at the same time interval, significantly decreased $\alpha 3$ integrin expression at the protein level, as evaluated by Western blot analysis (Fig. 3B).

GnRH agonists reduce MMP-2 expression and activity in melanoma cells. The matrix metalloproteinases (MMPs) have
A)

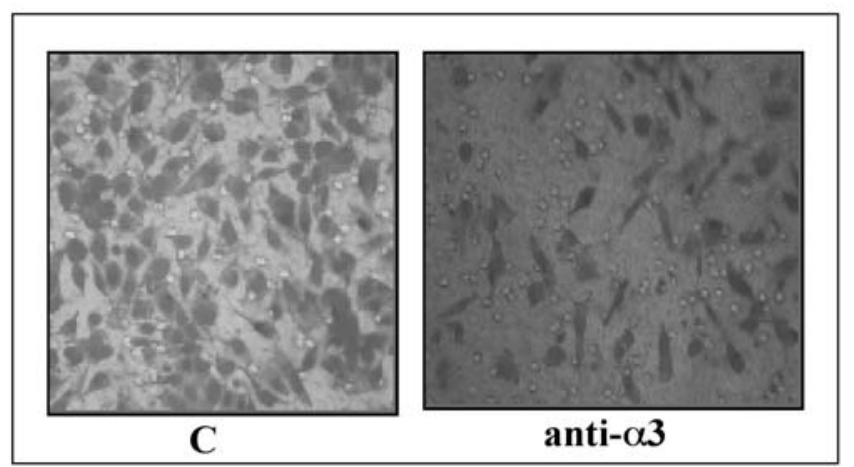

B)

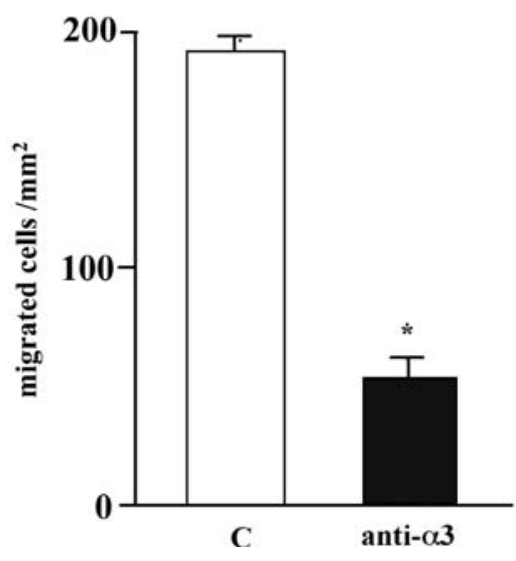

Figure 2. Effects of a function-blocking antibody against $\alpha 3$ integrin on the migratory behavior of melanoma cells. BLM cells were treated for $1 \mathrm{~h}$ with a function-blocking antibody against $\alpha 3$. Cells were then seeded in the openbottom wells of the upper compartment of a Boyden chamber, for which the lower surface had been precoated with laminin (chemoattractant). (A) Stained cells migrating towards the underside of the wells. (B) Statistical evaluation of the results. Data are expressed as the mean cell number of migrated cells $/ \mathrm{mm}^{2} \pm \mathrm{SE} .{ }^{*} \mathrm{P}<0.05$ vs. C, controls.

been widely shown to play a crucial role in melanoma progression to metastases $(13,14)$. BLM cells, in particular, express MMP-2 and its specific tissue inhibitor TIMP-2 $(13,31)$. Experiments have been performed to clarify whether GnRH agonists might exert their in vitro antimetastatic activity by affecting the expression and/or activity of the MMP-2/ TIMP-2 system. By comparative RT-PCR, we demonstrated that GnRH-A substantially reduced MMP-2 expression, starting at $24 \mathrm{~h}$, with a maximum inhibitory effect at $36 \mathrm{~h}$ of treatment (Fig. 4, upper panel). In the same experimental conditions, the GnRH agonist did not affect the expression of TIMP-2 (Fig. 5, upper panel). In both experiments, the expression of the housekeeping control gene $\beta$-actin was not modified by GnRH-A (Figs. 4 and 5, lower panels). By zymographic analysis, we then evaluated whether GnRH agonists might also reduce the activity of MMP-2 in the culture media of BLM cells. The densitometric analysis of the data obtained revealed that GnRH-A significantly reduced the amount of functionally active MMP-2, with a maximum effect at $72 \mathrm{~h}$ of treatment (Fig. $6 \mathrm{~A}$ and B). Thus, activation of $\mathrm{GnRH}$ receptors in melanoma cells exerts a significant 


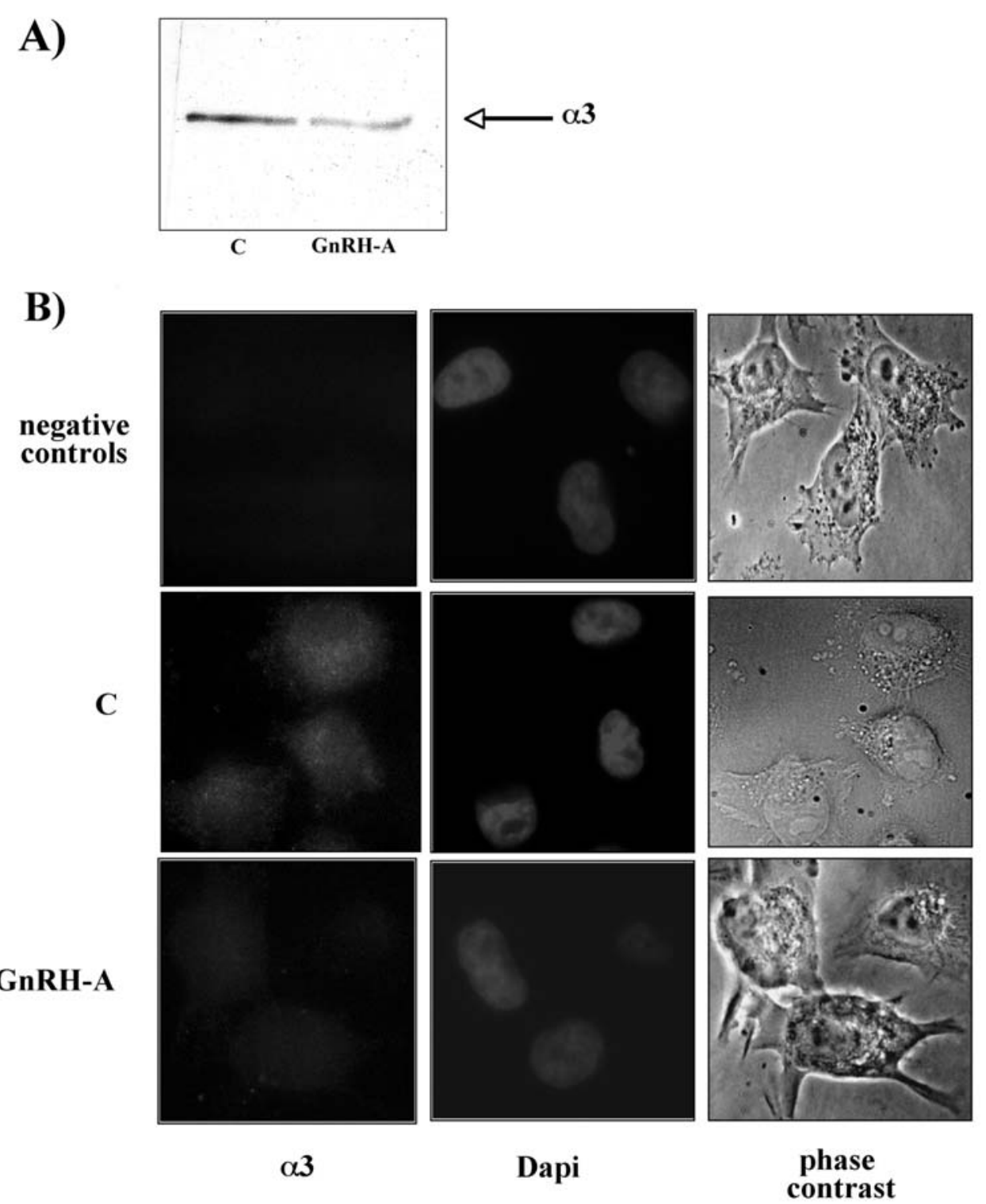

Figure 3. Effects of GnRH-A on $\alpha 3$ integrin expression in melanoma cells. BLM cells were treated for 5 days with GnRH-A (10 ${ }^{-6} \mathrm{M}$ ). The expression of $\alpha 3$ integrin was then analyzed by (A) Western blotting or (B) by immunofluorescence. (A) C, controls. (B) For negative controls, staining was performed in the absence of the primary antibody against $\alpha 3$ integrin. $\mathrm{C}$, controls.

inhibitory effect on both the expression and the activity of MMP-2.

\section{Discussion}

We previously reported that $\mathrm{GnRH}$ receptors are expressed in melanoma cells (BLM and Me15392), and their activation, achieved by means of GnRH agonists, significantly inhibits cell proliferation (28). In addition, we showed that these compounds also reduced the metastatic behavior of melanoma cells, as evaluated in terms of cell motility and invasive capacity (data here reported; 28). On the basis of these observations, experiments were performed to clarify the molecular mechanisms that might underlie the antimetastatic effect of GnRH agonists on BLM melanoma cells.

It is well known that tumor cell invasion and metastases largely depend on both adhesion (such as integrins) and proteolytic (such as matrix metalloproteinases, MMPs) molecules. Therefore, in BLM melanoma cells, we investigated the effects of the GnRH agonist GnRH-A on integrin and MMP expression/activity. First, we demonstrated that a function-blocking antibody against the $\alpha 3$ integrin subunit significantly reduced the ability of BLM melanoma cells to migrate towards laminin, a protein of the extracellular matrix. Thus, $\alpha 3$ integrin, by interacting with laminin, is deeply involved in the regulation of BLM cell motility, as previously shown for A375 and Mewo melanoma cells (9). On the basis of these preliminary observations, we then investigated whether the expression of $\alpha 3$ integrin might be affected by GnRH agonists. We demonstrated that GnRH-A substantially decreased $\alpha 3$ integrin expression, as evaluated by Western blotting and by immunofluorescence analysis. Among the different proteolytic enzymes known to degrade the extracellular matrix components, MMP-2 has been specifically reported to play a crucial role in the regulation of the metastatic behavior of melanoma cells $(14,32)$. Over- 
MMP-2

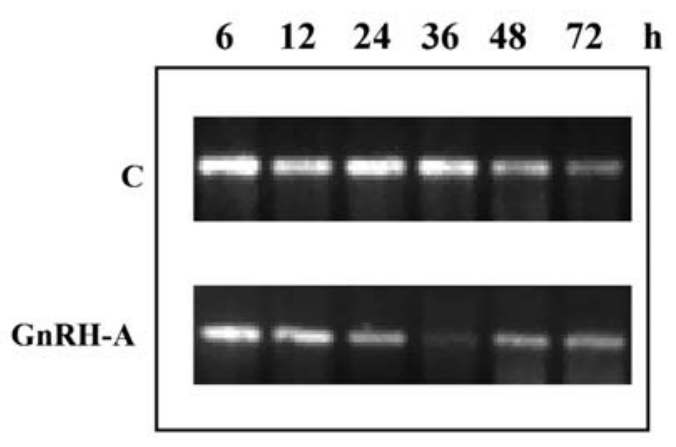

$\beta$-actin

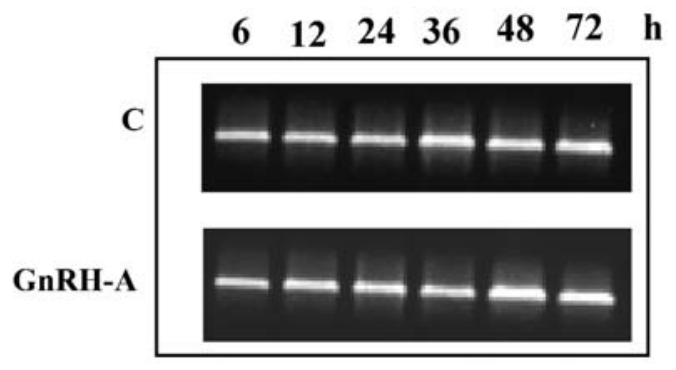

Figure 4. Effects of GnRH-A on MMP-2 expression in melanoma cells. BLM cells were treated with GnRH-A $\left(10^{-6} \mathrm{M}\right)$ for different time intervals (6-72 h). MMP-2 mRNA levels were analyzed by RT-PCR (upper panel). The housekeeping gene B-actin was used as a standard (lower panel). C, controls. One out of three experiments performed is shown.

\section{TIMP-2}

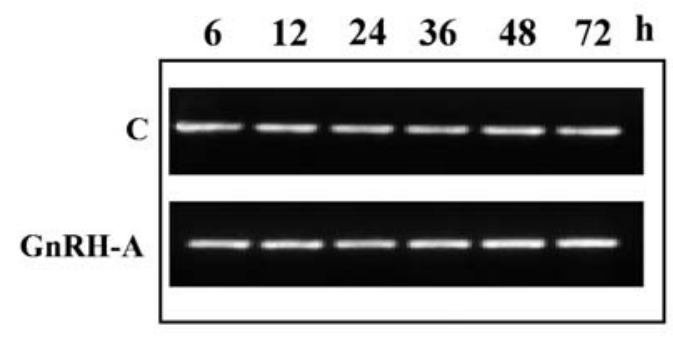

$\beta$-actin

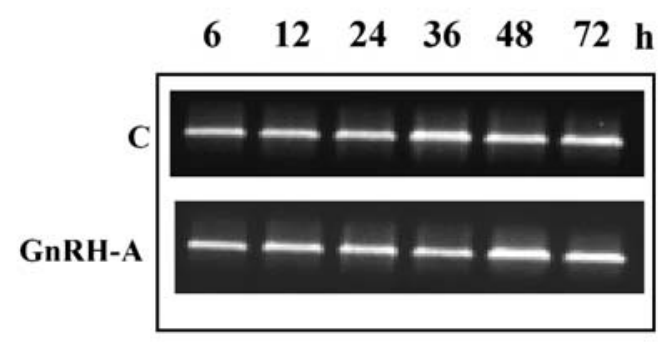

Figure 5. Effects of GnRH-A on TIMP-2 expression in melanoma cells. BLM cells were treated with GnRH-A $\left(10^{-6} \mathrm{M}\right)$ for different time intervals (6-72 h). TIMP-2 mRNA levels were analyzed by RT-PCR (upper panel). The housekeeping gene $\mathrm{B}$-actin was used as a standard (lower panel). C, controls. One out of three experiments performed is shown.

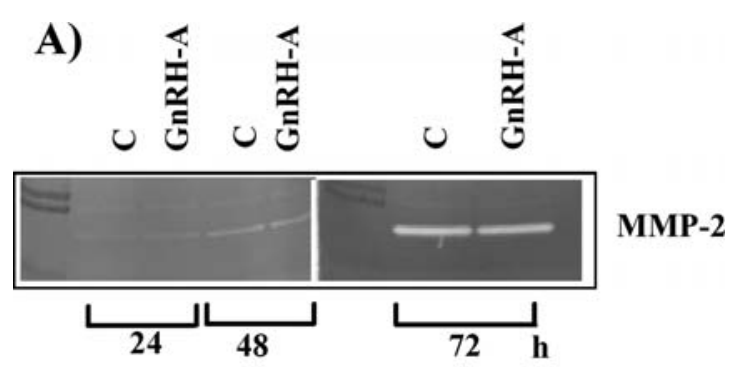

B)

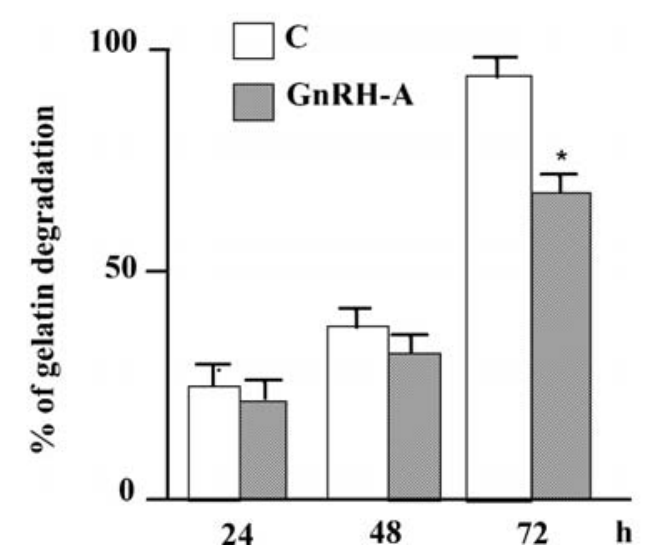

Figure 6. Effects of GnRH-A on MMP-2 activity in the culture media of melanoma cells. (A) BLM cells, grown in serum-free medium, were treated with GnRH-A ( $\left.10^{-6} \mathrm{M}\right)$ for different time intervals $(24-72 \mathrm{~h})$. The conditioned media from the cells were collected, and the activity of MMP-2 was analyzed by zymography. One out of three experiments performed is shown. (B) Statistical evaluation of the densitometric analysis of the bands obtained from the zymographic analyses. C, controls.

expression of MMP-2 has been shown to be associated with tumor progression in human melanocytic tumors (33-35). More recently, on the basis of clinical observations, Vaisanen and coworkers (36) proposed that MMP-2 expression might represent a strong prognostic marker for melanoma-related death. In the present study, we demonstrated that, in BLM melanoma cells, the GnRH agonist GnRH-A significantly decreased intracellular MMP-2 expression as well as the MMP-2 gelatinolytic activity in the culture media of the cells.

Our results demonstrated that $\mathrm{GnRH}$ agonists exert a significant inhibitory action on both the motility and the invasive behavior of melanoma cells by reducing the expression/activity of cell adhesion molecules ( $\alpha 3$ integrin) and of MMP-2. These data, together with the previously observed antiproliferative effect of GnRH-A on BLM cells (28), strongly indicate that GnRH agonists may inhibit both the growth and the metastatic behavior of melanoma cells expressing the $\mathrm{GnRH}$ receptor.

In line with our observations, Keller and coworkers (37) reported the presence of GnRH receptors in human melanoma cell lines, as well as in human melanoma specimens derived 
from melanoma primary tumors or metastases. However, these authors did not directly address the specific role of these receptors in the control of melanoma growth and metastatic progression. In their study, Keller and coworkers (37) considered GnRH receptors in melanoma cells as a molecular target for conjugated compounds consisting of a GnRH agonist [D-Lys ${ }^{6}$ GnRH linked to cytotoxic radicals (doxorubicin or its derivative 2-pyrrolidino-doxorubicin). Thus, in their studies, these authors utilized the GnRH agonist as a carrier molecule which, through its binding to GnRH receptors on melanoma cells, can specifically direct cytotoxic compounds to the tumor. Keller and coworkers (37) demonstrated that the cytotoxic conjugates significantly inhibit the growth of melanoma xenografts in nude mice. Their study also demonstrated that the GnRH agonist, when administered as a single drug, did not exert any significant effect on tumor growth. However, it must be emphasized that, in these studies, nude mice bearing melanoma xenografts were treated only twice with the GnRH analogue (on days 1 and 15 of the experiment), before being sacrificed on day 29 . In a prevous study, in which we addressed the effect of GnRH agonists on the growth of prostate cancer xenografts in nude mice, we showed that a continuous release of the compound from osmotic minipumps, for up to 14 days, was required to obtain a significant inhibitory action on tumor growth (38).

The presence of GnRH receptors, and their possible role as molecular targets for GnRH analogue-based antitumor therapeutical approaches, have been previously shown for tumors of the reproductive system, both male and female. In our laboratory, we demonstrated that $\mathrm{GnRH}$ receptors are expressed in prostate cancer cells and that GnRH agonists significantly reduce both proliferation and the metastatic behavior of these cells $(30,38-42)$. These compounds exert their effect by interfering with the growth-promoting and prometastatic activity of growth factors, such as EGF and IGF-I $(30,43,44)$. In line with our experimental results, a direct antitumor activity of GnRH agonists on prostate cancer is supported by recent clinical observations (45). A direct antiproliferative and antimetastatic activity of GnRH agonists was also demonstrated for breast cancer cells (46-48). Yet, contrasting results have been reported for ovarian cancer. While it is widely accepted that activation of locally expressed GnRH receptors significantly decreases ovarian tumor cell proliferation $(24,49,50)$, a recent study by Cheung et al (51) seems to suggest that GnRH agonists may stimulate, rather than inhibit, the motility and the invasiveness of these cells, through activation of MMP-2 and -9. At present, the reason for this discrepancy is unclear; however, we believe that the specific experimental conditions adopted in the different studies might be responsible (cell lines, dose of GnRH agonists, length of the treatments).

Finally, in line with our results, GnRH receptors have also been detected in tumors unrelated to the reproductive system, other than melanoma (52-54). In particular, van Groeninghen and coworkers (55) reported the presence of GnRH-binding sites in biopsies from glioblastoma patients. In light of this, it must be noted that both glial cells and melanocytes share the same neuroectodermal origin.

In conclusion, the data reported in this study, together with our previous observations (28), indicate that GnRH agonists, through the activation of specific receptors, reduce, not only the proliferation, but also the migratory/invasive behavior of melanoma cells. Thus, we suggest that the GnRH receptor might represent a novel molecular target for the development of new target-directed therapeutic interventions in melanoma. As previously mentioned, the prognosis of metastatic melanoma is still very poor due to its resistance to existing therapies. Cytotoxic compounds, such as dacarbazine, have been reported to be associated with a modest anti-tumor activity but with significant side effects $(5,6,56)$. Immunotherapy, performed by both active (vaccination) and passive (adoptive) approaches, as well as the use of cytokines (interferon- $\alpha$, IL-2) have demonstrated only a limited clinical outcome $(7,57)$. Novel therapeutical approaches, based on the combination of standard chemotherapy and immunotherapy, have been proposed and are at present under evaluation (8). On the basis of these unsatisfactory results, oncologists are now concentrating their efforts on the development of novel molecular therapies, based on agents that might interfere with the biological mechanisms involved in melanoma growth and progression $(56,58-60)$. Therefore, preclinical studies with nude mice are currently underway in our laboratory to further support the possible role of GnRH receptors as novel biological targets for the improvement of therapeutical approaches for melanoma.

\section{Acknowledgements}

This study was supported by 'Fondazione Cariplo' and by The Center of Endocrinological Oncology, University of Milan.

\section{References}

1. Demierre MF: Epidemiology and prevention of cutaneous melanoma. Curr Treat Options Oncol 7: 181-186, 2006.

2. Jemal A, Siegel R, Ward E, Murray T, Xu J and Thun MJ: Cancer statistics, 2007. CA Cancer J Clin 57: 43-66, 2007.

3. Garbe C: Cutaneous melanoma: baseline and ongoing laboratory evaluation. Dermatol Ther 18: 413-421, 2005.

4. Pharis DB: Cutaneous melanoma: therapeutic lymph node and elective lymph node dissections, lymphatic mapping, and sentinel lymph node biopsy. Dermatol Ther 18: 397-406, 2005.

5. Khayat D, Bernard-Marty C, Meric JB and Rixe O: Biochemotherapy for advanced melanoma: maybe it is real. J Clin Oncol 20: 2045-2052, 2002.

6. Mandarà M, Nortilli R, Sava T and Cetto GL: Chemotherapy for metastatic melanoma. Expert Rev Anticancer Ther 6: 121-130, 2006.

7. Parmiani G, Castelli C, Santinami M and Rivoltini L: Melanoma immunology: past, present and future. Curr Opin Oncol 19: 121-127, 2007.

8. Sasse AD, Sasse EC, Clark LG, Ulloa L and Clark OA: Chemoimmunotherapy versus chemotherapy for metastatic malignant melanoma. Cochrane Database Syst Rev 24: CD005413, 2007.

9. Tsuji T, Kawada Y, Kai-Murozono M, Komatsu S, Han SA, Takeuchi K, Mizushima H, Miyazaki K and Irimura T: Regulation of melanoma cell migration and invasion by laminin-5 and $\alpha 3 \beta 1$ integrin (VLA-3). Clin Exp Metastasis 19: 127-134, 2002.

10. Kuphal S, Bauer R and Bosserhoff AK: Integrin signaling in malignant melanoma. Cancer Metastasis Rev 24: 195-222, 2005 .

11. Bosserhoff AK: Novel biomarkers in malignant melanoma. Clin Chim Acta 367: 28-35, 2006.

12. Watson-Hurst K and Becker D: The role of N-cadherin, MCAM and beta3 integrin in melanoma progression, proliferation, migration and invasion. Cancer Biol Ther 5: 1375-1382, 2006.

13. Hofmann UB, Westphal JR, van Muijen GNP and Ruiter DJ: Matrix metalloproteinases in human melanoma. J Invest Dermatol 115: 337-344, 2000. 
14. Redondo P, Lloret P, Idoate $M$ and Inogest $S$ : Expression and serum levels of MMP-2 and MMP-9 during human melanoma progression. Clin Exp Dermatol 30: 541-545, 2005.

15. Nyormoi $\mathrm{O}$ and Bar-Eli M: Transcriptional regulation of metastasis-related genes in human melanoma. Clin Exp Metastasis 20: 251-263, 2003.

16. Dadras SS and Detmar M: Angiogenesis and lymphangiogenesis of skin cancers. Hematol Oncol Clin North Am 18: 1059-1070, 2004.

17. Fidler IJ: The pathogenesis of cancer metastasis: the 'seed and soil' hypothesis revisited. Nat Rev Cancer 3: 453-458, 2003.

18. Schally AV: Hypothalamic hormones: from neuroendocrinology to cancer therapy. Anticancer Drugs 5: 115-130, 1994

19. Covens A, Thomas G, Shaw P, Ackerman I, Osborne R, Lukka H, Carey M, Fraussen E and Rochie K: A phase II study of leuprolide in advanced/recurrent endometrial cancer. Gynecol Oncol 64: 126-129, 1997.

20. Labrie F, Belanger A, Luu-The V, Labrie C, Simard J, Cusan L, Gomez J and Candas B: Gonadotropin-releasing hormone agonists in the treatment of prostate cancer. Endocr Rev 26: 361-379, 2005.

21. Engel JB and Schally AV: Drug insight: clinical use of agonists and antagonists of luteinizing-hormone-releasing hormone. Nat Clin Pract Endocrinol Metab 3: 157-167, 2007.

22. Tan SH and Wolff AC: Luteinizing hormone-releasing hormone agonists in premenopausal hormone receptor-positive breast cancer. Clin Breast Cancer 7: 455-464, 2007.

23. Limonta P, Montagnani Marelli M and Moretti RM: LHRH analogues as anticancer agents: pituitary and extrapituitary sites of action. Exp Opin Invest Drugs 10: 709-720, 2001.

24. Grundker C, Gunthert AR, Westphalen S and Emons G: Biology of the gonadotropin-releasing hormone system in gynecological cancers. Eur J Endocrinol 146: 1-14, 2002.

25. Limonta P, Moretti RM, Montagnani Marelli M and Motta M: The biology of gonadotropin-releasing hormone: role in the control of tumor growth and progression in humans. Front Neuroendocrinol 24: 279-295, 2003.

26. Harrison GS, Wierman ME, Nett TM and Glode LM: Gonadotropin-releasing hormone and its receptor in normal and malignant cells. Endocr Relat Cancer 11: 725-748, 2004.

27. Montagnani Marelli M, Moretti RM, Januszkiewicz-Caulier J, Motta M and Limonta P: Gonadotropin-releasing hormone $(\mathrm{GnRH})$ receptors in tumors: a new rationale for the therapeutical application of GnRH analogs in cancer patients? Curr Cancer Drug Targets 6: 257-269, 2006.

28. Moretti RM, Montagnani Marelli M, van Groeninghen JC and Limonta P: Locally expressed luteinizing hormone-releasing hormone (LHRH) receptors mediate the oncostatic and antimetastatic activity of LHRH agonists on melanoma cells. J Clin Endocrinol Metab 87: 3791-3797, 2002.

29. van Muijen GNP, Cornelissen IMHA, Jansen CFJ, Figdor CG, Johnson JP, Brocker EB and Ruiter DJ: Antigen expression of metastasizing and non-metastasizing human melanoma cells xenografted into nude mice. Clin Exp Metastasis 9: 259-272, 1991 .

30. Montagnani Marelli M, Moretti RM, Mai S, Procacci P and Limonta P: Gonadotropin-releasing hormone agonists reduce the migratory and the invasive behavior of androgenindependent prostate cancer cells by interfering with the activity of IGF-I. Int J Oncol 30: 261-271, 2007.

31. Hofmann UB, Westphal JR, Waas ET, Zendman AJW, Cornelissen IMHA, Ruiter DJ and van Muijen GNP: Matrix metalloproteinases in human cell lines and xenografts: increased expression of activated matrix metalloproteinase-2 (MMP-2) correlates with melanoma progression. Br J Cancer 81: 774-782, 1999.

32. Banerji A, Chakraborti J, Mitra A and Chatterjee A: Cell membrane-associated MT1-MMP-dependent activation of proMMP-2 in A375 melanoma cells. J Environ Pathol Toxicol Oncol 24: 3-17, 2005.

33. Vaisanen A, Tuominen $\mathrm{H}$, Kallioinen $\mathrm{M}$ and Turpeenniemi-Hujanen $\mathrm{T}$ : Matrix metalloproteinase-2 (72 kDa type IV collagenase) expression occurs in the early stage of human melanocytic tumor progression and may have prognostic value. J Pathol 80: 283-289, 1996.

34. Hofmann UB, Westphal JR, Zendman AJ, Becker JC, Ruiter DJ and van Muijen GN: Expression and activation of matrix metalloproteinase-2 (MMP-2) and its co-localization with membrane-type 1 matrix metalloproteinase (MT1-MMP) correlate with melanoma progression. J Pathol 191: 245-256, 2000.
35. Simonetti O, Lucarini G, Brancorsini D, Nita P, Bernardini ML, Biagini $\mathrm{G}$ and Offidani $\mathrm{A}$ : Immunohistochemical expression of vascular endothelial growth factor, matrix metalloproteinase 2, and matrix metalloproteinase 9 in cutaneous melanocytic lesions. Cancer 95: 1963-1970, 2002.

36. Vaisanen AH, Kallioinen M and Turpeenniemi-Hujanen T: Comparison of the prognostic value of matrix metalloproteinases 2 and 9 in cutaneous melanoma. Hum Pathol 39: 377-385, 2008.

37. Keller G, Schally AV, Gaiser T, Nagy A, Baker B, Westphal G, Halmos G and Engel JB: Human malignant melanomas express receptors for luteinizing hormone releasing hormone allowing targeted therapy with cytotoxic luteinizing hormone releasing hormone analogue. Cancer Res 65: 5857-5863, 2005.

38. Dondi D, Moretti RM, Montagnani Marelli M, Pratesi G, Polizzi D, Milano M, Motta M and Limonta P: Growth-inhibitory effects of luteinizing hormone-releasing hormone (LHRH) agonists on xenografts of the DU 145 human androgenindependent prostate cancer cell line in nude mice. Int J Cancer 76: 506-511, 1998.

39. Limonta P, Dondi D, Moretti RM, Maggi R and Motta M: Antiproliferative effects of luteinizing hormone releasing hormone agonists on the human prostatic cancer cell line LNCaP. J Clin Endocrinol Metab 75: 207-212, 1992.

40. Limonta P, Dondi D, Moretti RM, Fermo D, Garattini E and Motta M: Expression of luteinizing hormone-releasing hormone mRNA in the human prostatic cancer cell line LNCaP. J Clin Endocrinol Metab 76: 797-800, 1993.

41. Dondi D, Limonta P, Moretti RM, Montagnani Marelli M, Garattini E and Motta M: Antiproliferative effects of luteinizing hormone-releasing hormone (LHRH) agonists on human androgen-independent prostate cancer cell line DU 145: evidence for an autocrine-inhibitory LHRH loop. Cancer Res 54: 4091-4095, 1994.

42. Limonta P, Moretti RM, Montagnani Marelli M, Dondi D, Parenti $\mathrm{M}$ and Motta $\mathrm{M}$ : The luteinizing hormone-releasing hormone receptor in human prostate cancer cells: messenger ribonucleic acid expression, molecular size, and signal transduction pathway. Endocrinology 140: 5250-5256, 1999.

43. Moretti RM, Montagnani Marelli M, Dondi D, Poletti A, Martini L, Motta M and Limonta P: Luteinizing hormonereleasing hormone agonists interfere with the stimulatory actions of epidermal growth factor in human prostatic cancer cell lines, LNCaP and DU 145. J Clin Endocrinol Metab 81: 3930-3937, 1996.

44. Montagnani Marelli M, Moretti RM, Dondi D, Motta M and Limonta P: Luteinizing hormone-releasing hormone agonists interfere with the mitogenic activity of the insulin-like growth factor system in androgen-independent prostate cancer cells. Endocrinology 140: 329-334, 1999.

45. Gnanapragasam VJ, Darby S, Khan MM, Lock WG, Robson CN and Leung HY: Evidence that prostate gonadotropin-releasing hormone receptors mediate an antitumorigenic response to analogue therapy in hormone refractory prostate cancer. J Pathol 206: 205-213, 2005

46. Miller WR, Scott WN, Morris R, Fraser HM and Sharpe R: Growth of human breast cancer cells inhibited by a luteinizing hormone-releasing hormone agonist. Nature 313: 231-233, 1985.

47. Harris N, Dutlow C, Eidne K, Dong KW, Roberts J and Millar R: Gonadotropin-releasing hormone gene expression in MDA-MB231 and ZR-75-1 breast carcinoma cell lines. Cancer Res 51: 2577-2581, 1991

48. Cheng CK and Leung PC: Molecular biology of gonadotropinreleasing hormone (GnRH)-I, GnRH-II, and their receptors in humans. Endocr Rev 26: 283-306, 2005.

49. Grundker C and Emons G: Role of gonadotropin-releasing hormone $(\mathrm{GnRH})$ in ovarian cancer. Reprod Biol Endocrinol 1: 65-71, 2003.

50. Kim KY, Choi KC, Auersperg N and Leung PC: Mechanism of gonadotropin-releasing hormone $(\mathrm{GnRH})-\mathrm{I}$ and -II-induced cell growth inhibition in ovarian cancer cells: role of the GnRH-I receptor and protein kinase $\mathrm{C}$ pathway. Endocr Relat Cancer 13: 211-220, 2006.

51. Cheung LWT, Leung PCK and Wong AST: Gonadotropinreleasing hormone promotes ovarian cancer cell invasiveness through c-Jun NH2-terminal kinase-mediated activation of matrix metalloproteinase (MMP)-2 and MMP-9. Cancer Res 66: 10902-10910, 2006 
52. Keller G, Schally AV, Gaiser T, Nagy A, Baker B, Halmos G and Engel JB: Receptors for luteinizing hormone releasing hormone expressed on human renal cell carcinomas can be used for targeted chemotherapy with cytotoxic luteinizing hormone releasing hormone analogues. Clin Cancer Res 11: 5549-5557, 2005.

53. Keller G, Schally AV, Gaiser T, Nagy A, Baker B, Halmos G and Engel JB: Receptors for luteinizing hormone releasing hormone (LHRH) expressed in human non-Hodgkin's lymphomas can be targeted for therapy with the cytotoxic LHRH analogue AN-207. Eur J Cancer 41: 2196-2202, 2005.

54. Szepeshazi K, Schally AV and Halmos G: LH-RH receptors in human colorectal cancers: unexpected molecular targets for experimental therapy. Int J Oncol 30: 1485-1492, 2007.

55. van Groeninghen JC, Kiesel L, Winkler D and Zwirner M: Effects of luteinising hormone-releasing hormone on nervous-system tumours. Lancet 352: 372-373, 1998.
56. Becker JC, Kirkwood JM, Agarwala SS, Dummer R, Schrama D and Hauschild A: Molecular targeted therapy for melanoma. Cancer 107: 2317-2327, 2006.

57. Kirkwood JM, Moschos S and Wang W: Strategies for the development of more effective adjuvant therapy of melanoma: current and future explorations of antibodies, cytokines, vaccines, and combinations. Clin Cancer Res 12: 2331s-2336s, 2006.

58. Kalinsky K and Haluska FG: Novel inhibitors in the treatment of metastatic melanoma. Expert Rev Anticancer Ther 7: 715-724, 2007.

59. Gray-Schopfer V, Wellbrock C and Marais R: Melanoma biology and new targeted therapy. Nature 445: 851-857, 2007.

60. Lejeune FJ, Rimoldi D and Speiser D: New approaches in metastatic melanoma: biological and molecular targeted therapies. Expert Rev Anticancer Ther 7: 701-713, 2007. 